\title{
THE RELEASE OF HYALURONIDASE FROM GUINEA-PIG SPERMATOZOA DURING THE COURSE OF THE NORMAL ACROSOME REACTION IN VITRO
}

\author{
PRUDENCE TALBOT AND L. E. FRANKLIN \\ Department of Biology, University of Houston, Houston, Texas 77004, U.S.A.
}

(Received 22nd February 1974)

Hamster spermatozoa incubated in heat-pretreated blood serum release 55 to $60 \%$ of their total hyaluronidase activity by the end of $1 \mathrm{hr}$ of incubation; little increase in activity is found in the incubation medium at later time intervals up to $4 \mathrm{hr}$ (Rogers \& Morton, 1973; Talbot \& Franklin, 1974b). This release occurs well before and independently of a normal acrosome reaction, i.e. detachment of the acrosome from motile spermatozoa as observed with phasecontrast microscopy (Talbot \& Franklin, 1974b). Vesiculation between the outer acrosomal membrane and plasma membrane does not occur before the surge of hyaluronidase release which takes place between time zero and $1 \mathrm{hr}$ of incubation (Talbot \& Franklin, 1974b).

Lewis \& Ketchel (1972a, 1973) demonstrated that the release of hyaluronidase from rabbit spermatozoa incubated in postovulatory uterine fluid is "related to the completion of the process of capacitation". Although acrosome detachment is not easily monitored for this species, their data imply that hyaluronidase release occurs before a normal acrosome reaction. The complex incubation media used for studies of both hamster and rabbit spermatozoa contain a macromolecular factor(s) which promotes hyaluronidase release in vitro (Lewis \& Ketchel, 1972b; Rogers \& Morton, 1973; Talbot \& Franklin, 1974b).

Recently, several chemically defined media have been developed which support the occurrence of a normal acrosome reaction in guinea-pig spermatozoa (Barros, Berrios \& Herrera, 1973; Barros, 1974). This investigation was undertaken to compare the release of hyaluronidase from guinea-pig spermatozoa incubated in a chemically defined medium with its release from guineapig and hamster spermatozoa incubated in heat-pretreated blood serum.

In the first experiment, the time course of hyaluronidase release from guinea-pig spermatozoa incubated in a chemically defined medium was monitored. Spermatozoa from the cauda epididymidis of sexually mature males were washed twice in $4 \mathrm{ml}$ normal saline. Falcon centrifuge tubes (catalogue No. 2095) containing minimum capacitation medium (MCM) (Barros, 1974) or calcium-free MCM were inoculated with washed spermatozoa $\left(1 \times 10^{7}\right.$ spermatozoa $/ 0.5 \mathrm{ml}$ ) and incubated in a horizontal position at $37^{\circ} \mathrm{C}$ in air. At time zero and at hourly intervals thereafter up to $4 \mathrm{hr}$, the percentage of motile spermatozoa without acrosomes (normal acrosome reactions) and the 
percentage of immotile spermatozoa without acrosomes (degenerative acrosome reactions) were determined for an incubation tube. Spermatozoa were centrifuged out of the incubation medium, and the supernatant was assayed for hyaluronidase activity using the turbidimetric procedure (Tolksdorf, McCready, McCullagh \& Schwenk, 1949). The results (Text-fig. 1) indicate that the percentage of normal acrosome reactions which occurred in MCM increased with time and reached a peak by $4 \mathrm{hr}$. Hyaluronidase activity in this incubation medium increased as the percentage of normal acrosome reactions increased.

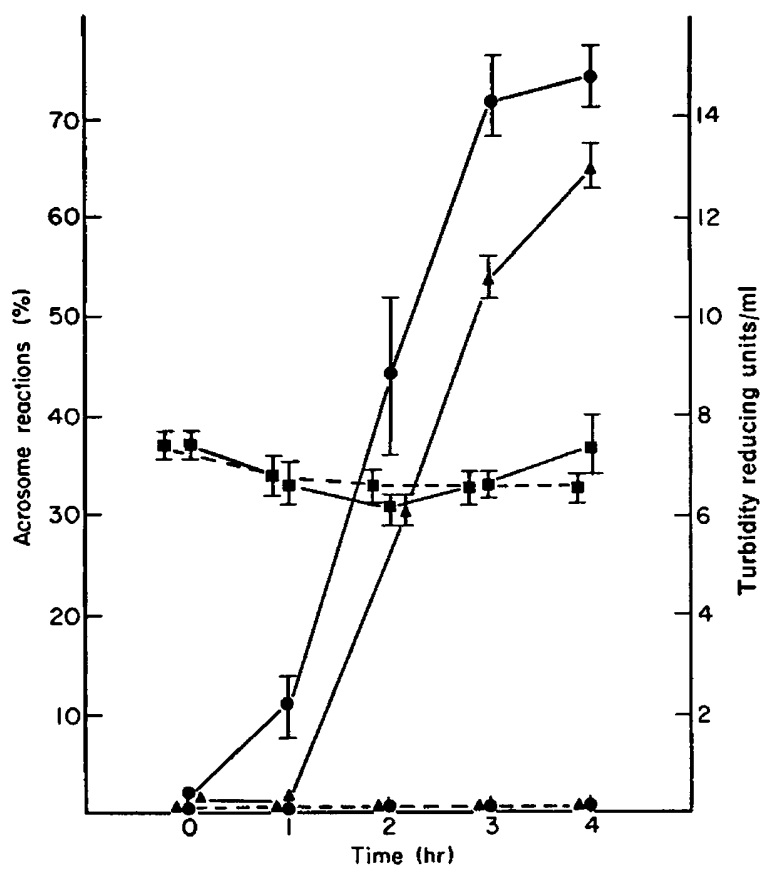

Text-Fig. 1. Acrosome detachment and release of hyaluronidase from guinea-pig spermatozoa during incubation in minimum capacitation medium (MCM) and calcium-free MCM. - - , Percentage of normal acrosome reactions, MCM; $-\square$, percentage of degenerative acrosome reactions, MCM; $\Delta-\Lambda$, turbidity reducing units (TRU) of hyaluronidase/ml, MCM; - - percentage of normal acrosome reactions, calcium-free $\mathrm{MCM}$; $\mathbf{- 1 -}-\mathbf{n}$, percentage of degenerative acrosome reactions, calcium free MCM; $\Delta---\Delta$, TRU of hyaluronidase/ml, calcium free MCM. Each point is the mean \pm S.E. of four experiments.

The percentage of degenerative acrosome reactions did not change significantly, indicating that the hyaluronidase released from spermatozoa in MCM was not correlated with an increase in cell deaths. Spermatozoa incubated in calciumfree MCM did not undergo either degenerative or normal acrosome reactions and did not release detectable hyaluronidase activity during the incubation period.

The time course for hyaluronidase liberation from guinea-pig spermatozoa in MCM differed markedly from the previously described time course for hyaluronidase liberation from hamster spermatozoa in heat-pretreated serum (Rogers \& Morton, 1973; Talbot \& Franklin, 1974b). In the hamster, a surge 
of release was complete by $\mathrm{I} \mathrm{hr}$ of incubation, well before the normal acrosome reaction, and a significant increase in activity was not detected at later time intervals. A second experiment was performed to determine if the observed disparity in hyaluronidase release from guinea-pig and hamster spermatozoa was due to the presence of a hyaluronidase-releasing factor in serum or to a species difference. Washed guinea-pig or hamster spermatozoa were incubated in heat-pretreated $\left(60^{\circ} \mathrm{C}\right.$ for $1 \mathrm{hr}$ ) blood serum (calf or baboon) diluted $1: 1$

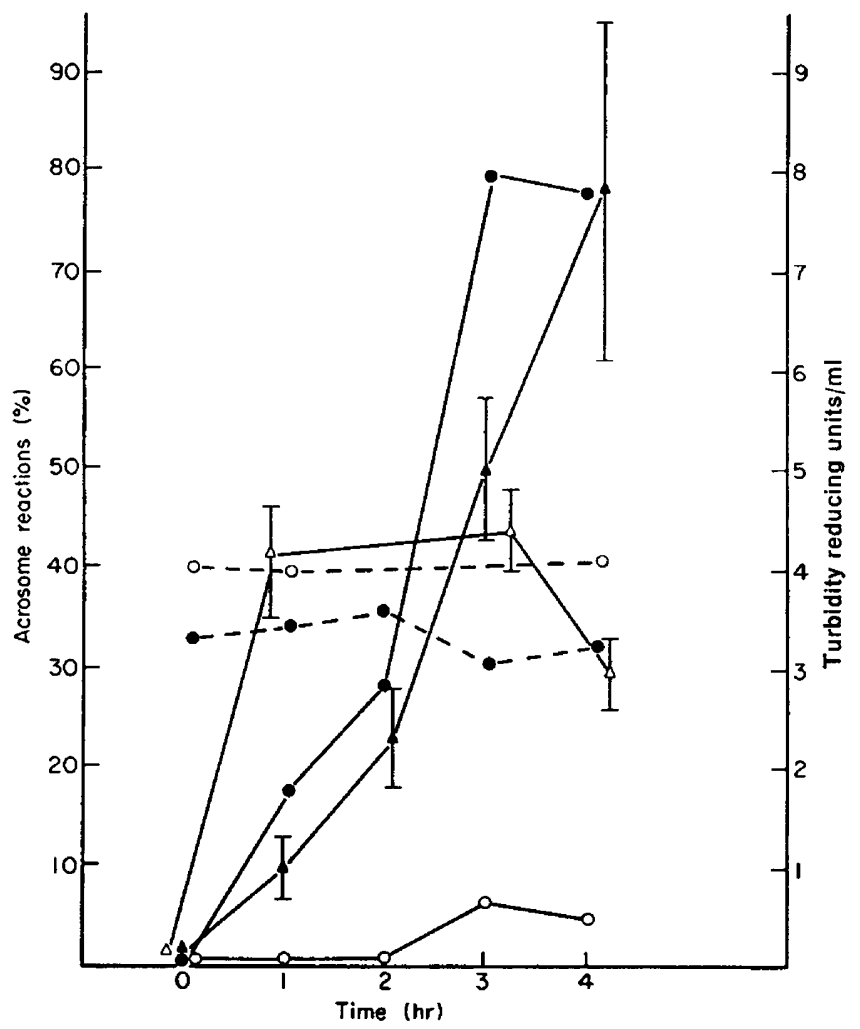

TEXT-FIG. 2. Acrosome detachment and the release of hyaluronidase from hamster and guinea-pig spermatozoa in heat-pretreated calf serum. Guinea-pig: $-\longrightarrow$, percentage of normal acrosome reactions; - - $\Lambda-\Lambda$, turbidity reducing units (TRU) of hyaluronidase/ml. Hamster: $\mathrm{O}-\mathrm{O}$, percentage of normal acrosome reactions; $O_{--} \mathrm{O}$, percentage of degenerative acrosome reactions; $\Delta-\Delta$, TRU of hyaluronidase $/ \mathrm{ml}$. Each hyaluronidase assay is the mean of four trials \pm S.E. Each percentage of acrosome detachment is based on a count of 100 spermatozoa; for normal acrosome reactions only motile spermatozoa were counted.

with MCM using the techniques previously described. Following incubation, degenerative and normal acrosome reactions were monitored and sperm-free supernatants were assayed for hyaluronidase activity using the procedure of Talbot \& Franklin (1974a) which is compatible with complex incubation media. The results shown in Text-fig. 2 indicate that guinea-pig spermatozoa incubated in diluted serum liberated hyaluronidase as the percentage of normal acrosome reactions increased. Under the same incubation conditions, hamster 
spermatozoa completed a surge of hyaluronidase release by $1 \mathrm{hr}$ whether or not an increase in normal acrosome reactions occurred later during the incubation period.

We have concluded from this study that the mechanism for hyaluronidase release from spermatozoa differs with species. For the guinea-pig, release is directly correlated in time with detachment of the acrosome by means of a normal acrosome reaction. Although the fine structure of the guinea-pig sperm acrosome reaction remains to be described, these observations are compatible with the suggestion of Barros, Bedford, Franklin \& Austin (1967) that vesiculation between the plasma membrane and outer acrosomal membrane creates ports for the escape of enzymes including hyaluronidase. By contrast, more than $50 \%$ of the total hyaluronidase activity extractable from hamster spermatozoa by mechanical methods is clearly released before membrane vesiculation occurs (Talbot \& Franklin, 1974b). Spermatozoa of the rabbit (Lewis \& Ketchel, 1972a, 1973) and rhesus monkey (P. Talbot, unpublished data) are probably more similar to hamster spermatozoa in their pattern of hyaluronidase release as substantial activity appears in the incubation medium before the normal acrosome reaction is thought to occur. The physiological significance of the observed dissimilarity in the patterns of hyaluronidase release from spermatozoa of different species remains to be elucidated.

This research was supported by grant HD 07346 from the National Institutes of Health, Department of Health, Education, and Welfare. The authors are grateful to Dr C. Barros and Dr R. J. Talbot for their interesting discussions relating to this work, and to Professor C. R. Austin for reading the manuscript.

\section{REFERENCES}

Barros, C. (1974) Capacitation of mammalian spermatozoa. In Proc. Int. Symp. 'Physiologic and Genetic Aspects of Reproduction', Salvador, Bahia, Brazil, December 1973.

Barkos, G. Bedford, J. M., Franklin, L. E. \& Austin, G. R. (1967) Membrane vesiculation as a feature of the mammalian acrosome reaction. F. Cell Biol. 34, Cl.

Barros, G., Berrios, M. \& Herrera, E. (1973) Capacitation in vitro of guinea-pig spermatozoa in a saline solution. F. Reprod. Fert. 34, 547.

Lewis, B. K. \& Ketchel, M. M. (1972a) Effects of female reproductive tract secretions on rabbit sperm. I. Release of hyaluronidase in vitro. Proc. Soc. exp. Biol. Med. 141, 712.

LEwIS, B. K. \& Ketchel, M. M. (1972b) Effects of female reproductive tract secretions on rabbit sperm. II. Control of sperm hyaluronidase release. Proc. Soc. exp. Biol. Med. 141, 719.

Lewis, B. K. \& KETChel, M. M. (1973) Effects of female reproductive tract secretions on rabbit sperm. III. Acrosomal enzyme changes related to capacitation. Proc. Soc. exp. Biol. Med. 143, 540.

Rogers, B. J. \& Morton, B. E. (1973) The release of hyaluronidase from capacitating hamster spermmatozoa. J. Reprod. Fert. 35, 477.

TAlbot, P. \& Franklin, L. E. (1974a) Hamster sperm hyaluronidase. I. A bioassay procedure based on cumulus dispersion rate. F. exp. Zool. (in press).

TALBOT, P. \& FRANKLIN, L. E. (1974b) Hamster sperm hyaluronidase. II. Its release from sperm in vitro in relation to the degenerative and normal acrosome reaction. $\mathcal{F}$. exp. Zool. (in press).

Tolksdorf, S., McCready, M. H., McCullagh, D. R. \& Schwenk, E. (1949) The turbidimetric assay of hyaluronidase. F. Lab. clin. Med. 34, 74. 